\title{
Assessing the Challenges of Electricity Service Delivery Process: The Case of Shashego Woreda Electricity Sector, Hadiya Zone, Southern Ethiopia
}

\author{
Ageze Chufamo Gobena \\ Senior Lecturer and Researcher \\ Department of Civic \& Ethical Studies at Wachemo University, Ethiopia
}

\begin{abstract}
The main objective of this study was to assess the challenges of electricity service deliver process. Both quantitative and qualitative approaches were used for this study. This includes questionnaires, focused-group discussions, structured or semi-structured interviews, which are used as crucial data collection instrument. The sample size of this study was 384. Systematic random sampling was used to represent the households as part of the study. This was selected from Doisha and Bonosh twon residents. The Electricity sector is affected by lack of transparency, responsiveness, Moreover, the access to electricity is very low in this study area. For instance, the problem however is with the supply that breaks off basis due to power interruption. This, as about 58 per cent of respondents reported, occurs at least once in a week.
\end{abstract}

Keywords: challenges, service supply, electricity sector

DOI: $10.7176 / \mathrm{DCS} / 11-2-02$

Publication date: February $28^{\text {th }} 2021$

\section{INTRODUCTION}

Service delivery is an investigative process that provides the means which citizens achieve goals in a logical way. It indicates the delivery of inputs and outputs to achieve a certain outcomes leading to great socio-economic impacts on individuals, households and communities. The theme of service delivery can be conceptualized as handling interaction between policy makers, service providers and service seekers or consumers of services and includes both services and their supporting systems (UNDP, 2010).In the same source, adequate delivery of electricity is at the heart of urban levels of government function and makes this the sphere of government closest to the people. This is because an adequate supply of electricity is essential for economic development, because inadequate electricity supply hinders socioeconomic activities, restricts economic development and reduces the standard of living.

In this regard, the Ethiopian government has recognized the need for appropriate service delivery policy to encourage public service organizations improve their services to attain user satisfaction. However, the performance of Ethiopian Electric Power Corporation in providing quality service is not in a position to meet the expectation of service users. The complaints on the quality of service and response from the users for lack of the services were indicative of poor service delivery performance in the Corporation (Zeritu, 2010). Therefore, the objective of this study is to assess the challenges of electricity service delivery process..

\subsection{Objectives}

The general objective of the study is to assess the challenges of electricity supply process.

Based on this, the specific objectives of the study are the following: To

- Examine the nature of the electricity supply process.

- Assess the level of customer satisfaction on provisions.

- Identify Factors affecting adequate electricity supply process

\section{LITERATURE REVIEW}

\subsection{Conceptual framework}

According to Shimelis Alebachew (2003: 3-4) an urban area is said to be an effective when it provides those urban services that directly affect the quality of urban life, which include social services, and physical infrastructure services. Unfortunately, provision of electricity services has consistently failed to keep pace with increasing service demand in urban areas of Ethiopia. Many woredas have poor infrastructure to support transformation with electricity (Garci+a\&A.S. Rajkumar (2008, 57-61).

Urban management in broad sense contains a wide range of activities and the most important component is provision of urban public services .This implies, Citizen Satisfaction with the city environment and electricity services is an important factor to motivate people to participate in urban development and improving their living environment quality. Therefore, citizen satisfaction with electricity supply is an important factor attracting people to participate in improving the quality of urban setting (Goharipour, etal, 2011). Moreover, electricity 
supply is influenced by poor service delivery mechanisms such as inaccessibility, sustainability, lack of transparency and responsiveness to issues raised by communities, prone to corruption and with high degree of disregard for the communities. In line with this idea, Hanna (2011:7) stated that, in many developing countries, public sector corruption is a key barrier to adequate service delivery.

Oertel did a study (2004:24), the majority of the surveyed population does not have access to basic utilities such as reliable electricity (74\%). Moreover, commonly stated problems affecting these public services relate to inadequate facilities and resources combined with the lack of administrative and technical capacity at the local level

Sub-Saharan Africa is the most electricity-poor region in the world: Many people lack access to electricity, and several million people are connected to an unreliable grid that does not meet their daily energy service needs. Most countries in this region have average electricity access rate of about $20 \%$, and two out of three people lack access to modern energy services. Sub-Saharan Africa faces an electricity gap in two senses: a mismatch between supply and demand in grid-connected regions, and a lack of access in off-grid regions. Closing subSaharan Africa's electricity gap is a multidimensional challenge with important implications for how to frame the region's energy problem as a whole (Avila, N. etal, 2017). Similarly, based on Japanese report (2008), the access to energy in Ethiopia is relatively low, as little as $16 \%$, while the average access rate of Sub-Sahara Africa is $26 \%$.

\section{Methodology and Method of Collection}

\subsection{Description of the Study Area and Sites of Data Collection}

Shashogoworeda is one of the 10 woreda in Hadiya zone. It has of 103, 722 total population. It is located $224 \mathrm{~km}$ from capital city of Addis Ababa, and 54km from zonal city of Hossana. Administratively, the Woreda consists of two towns namely; Bonosha and Doisha, and 34 rural kebeles. Both were selected as centre of study area.

\subsubsection{Source of Population}

All residents who lived in the study area

\subsubsection{Study Population}

The study population was randomly selected households who lived at least for six months in the district.

\subsubsection{Inclusion and Exclusion criteria}

All selected households with 18and above years old households was included in the study. However, that household who was mentally and physically incapable of being interviewed during the study period and severely ill respondents was excluded from the study.

\subsection{Study Approach and Target population}

This study is dependent mainly on quantitative and qualitative approach. Target population of this study was households two town

\subsection{Inclusion and Exclusion criterion}

\subsubsection{Inclusive criteria}

$\checkmark$ Permanent resident of the two town (at least those who have lived for 1 years)

\subsubsection{Exclusive criteria}

$\checkmark \quad$ Those people who were severely ill or unable to respond and minority below the age of 18 years during the time of data collection were not approached.

\section{4 .Sample Size Determination and sampling procedure}

\section{4 .1. Sample Size Determination}

The desired sample size was obtained using single population proportion formula as follows:

$$
\mathrm{n}=\mathrm{Z}^{2} \mathrm{P}(1-\mathrm{P})
$$

Where: $\mathrm{n}=$ desired sample size

$$
\mathrm{z}=\text { the standard score corresponding to } 95 \% \text { confidence interval }
$$

$\mathrm{p}=$ prevalence of electricity supply problem

$$
\mathrm{d}=\text { margin of error (set at } 5 \% \text { ) }
$$$$
\mathrm{q}=1-\mathrm{p}
$$

Thus, $\mathrm{n}=(1.96)^{2} * 0.48 * 0.52 /(0.05)^{2}=384$

Therefore, the total sample size, using above formula for this study is 384 households. This total Sample size on the study is distributed to the two sub-city as follows using the following formula.

$\mathrm{ni}=\frac{N 1 \times n}{N}$

$\mathrm{N} 1$ represents household of Doisha , $\mathrm{N}$ is total number of households, ni is Doisha town' sample size and $\mathrm{n}$ is the 
total sampled size.

$\mathrm{ni}=\frac{N 2 x n}{N}$

$\mathrm{N} 2$ represents household of Bonosha town, $\mathrm{N}$ is total number of households, ni is Bonosha town sample size and $\mathrm{n}$ is the total sampled size.

Table 1: sampling frame.

\begin{tabular}{|l|l|l|l|}
\hline No. & Name of Town' & No. of total households & No .Sample size \\
\hline 1 & Doisha & 1800 & 69 \\
\hline 2 & Bonosha & 8200 & 315 \\
\hline & Total & 10,000 & 384 \\
\hline
\end{tabular}

\subsubsection{Sampling Procedure}

Two towns were included in the study. Systematic sampling technique was used. Study subject was selected by using systematic random sampling techniques until the required sample size was fulfilled from sample frames. Starting from a random point (1- $\mathrm{K}^{\text {th }}$ by lottery method) from the sampling frames, every $\mathrm{k}^{\text {th }}$ element in the frame was selected at equal intervals (sampling interval) from allocated numbers for each towns. The size of numbers was allocated for each town.

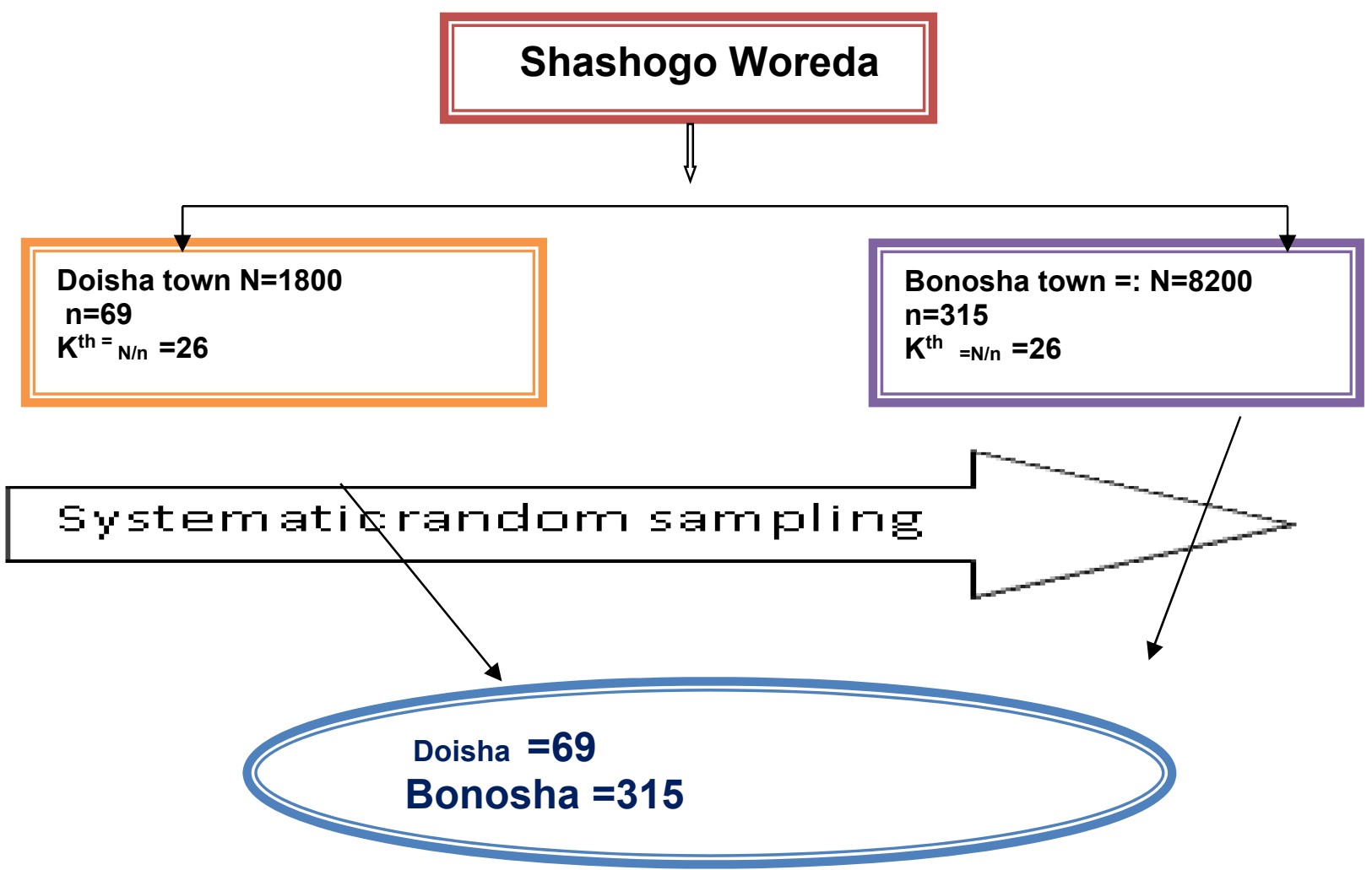

Figure 1 .The sampling procedure to select study subjects for the study on the challenges of electricity supply with reference to Shashogo woreda, Hadiya zone in 2018.

Sources: Thesis writer's assumption as developed based on field trip

\subsection{Study Design and Sampling Techniques}

Cross sectional study was conducted to assess challenges of electrify supply .A systematic random sampling technique was employed for households whereas the study area and the public institution were selected using purposive sampling techniques

\subsection{Study Variable:}

3.6.1. Dependent variable:

$\checkmark$ Adequate electricity supply -customary satisfaction

\subsubsection{Independent variables:}

Accessibility, Sustainability

Responsiveness, Transparency and Corruption 


\subsection{Sources of Data Collection}

Both secondary and primary data were sources of this study.

\subsection{The Nature of Data Collection Tools}

For the successful completion of this study, the researcher was used to collect the available data through following tools; namely, questionnaire, in depth interview, key informant interviews and focus group discussion, personal observation and document analysis.

\subsection{Data Analysis}

The collected questionnaire was checked manually for its completeness and was coded, entered in to Epi-data 3.1 and analyzed using SPSS version 20. Frequency or percentage (tables), bar graphs was used to represent results of categorical variables.

Qualitative data such as interview and focal group discussion was analyzed by transcribing informant's ideas and views through narrations, descriptions and discussions to help capture aspects of the research that could not be done through the quantitative method. In all statistical analysis, confidence level was held at $95 \%$ and $\mathrm{P}$-value is $<0.05$ (at $5 \%$ level of significance was considered as significant).

\section{Result and Discussion}

The study set out to assess the challenges of electricity supply. This part presents both results and discussions simultaneously based on the themes derived from the objectives of the study.

\subsection{Electricity Supply to Households}

Table 2: Electricity Supply process

\begin{tabular}{|c|c|c|c|c|c|}
\hline Variable & Category & Number & Percent (\%) & $\left(\chi^{2}\right)$ & P-value \\
\hline \multirow{3}{*}{$\begin{array}{l}\text { Is your household connected to } \\
\text { electricity network? }(n=384)\end{array}$} & Yes & 270 & $70.3 \%$ & \multirow[b]{3}{*}{2.574} & \multirow[b]{3}{*}{0.109} \\
\hline & No & 114 & $29.7 \%$ & & \\
\hline & Total & 384 & $100 \%$ & & \\
\hline \multirow{3}{*}{$\begin{array}{l}\text { Do you face electricity supply } \\
\text { problem? }(n=270)\end{array}$} & Yes & 264 & $96.3 \%$ & \multirow[b]{3}{*}{1.003} & \multirow[b]{3}{*}{0.000} \\
\hline & No & 6 & $5.6 \%$ & & \\
\hline & Total & 270 & $100 \%$ & & \\
\hline \multirow[t]{6}{*}{ How often? $(n=264)$} & Weekly & 153 & $58.0 \%$ & \multirow[b]{6}{*}{13.410} & \multirow[b]{6}{*}{0.009} \\
\hline & Monthly & 10 & $3.8 \%$ & & \\
\hline & Yearly & - & - & & \\
\hline & Rarely & 47 & $17.8 \%$ & & \\
\hline & Daily & 54 & $20.5 \%$ & & \\
\hline & Total & 264 & $100 \%$ & & \\
\hline
\end{tabular}

As item number 1 of the table 2 shows, from the 384 of the respondents, majority of them, $270(70.3 \%)$, have electricity access. Only 114 (29.7\%) of households do not have electricity access.

However, as item number 2 of the same table indicates, out of the 270 households, the greater percentages (96.3\%) of respondents have electricity supply problem whereas $(5.6 \%)$ of respondents do not have problems with electricity supply. Statistical analysis of the data shows the presence of significant association $\left(\chi^{2}=1.003, \mathrm{P}\right.$ $=0.000)$ of adequate electricity service with problems of electricity supply. Similarly, item number 3 of the same table reveals that respondents have been asked about how often the problem occurs. The majority 154 $(58.0 \%)$ of the respondents reported that electricity supply problem occurs at weekly basis and the remaining $3.8 \%, 17.8 \%$ and $20.5 \%$ of respondents indicated the electricity supply problem to occur once a month, rarely and daily, in respectively. As the result data shows, weekly interruptions $(58.0 \%)$ have significantly higher $\left(\chi^{2}=\right.$ $13.410, \mathrm{P}=0.009$ ) association rate of successful service delivery when compared to monthly, rarely and daily occurrence of the problems.

The participants in interviewees and focus group discussion also strongly support the idea that was gained through questionnaire. They have suggested that the main reason for electricity supply problem are lack of skilled personnel and insufficient number of qualified employees, inadequate facilities and resources cause ineffectiveness of service delivery. The finding of this study is higher than previous studies by Oertel (2004) around Addis Ababa, who reported that, the majority (74\%) of urban residents have problems with electricity supply, by Japanese report, (2008) the access to energy in Ethiopia is relatively low, as little as $16 \%$. 
Table 3: Frequency distribution according to the frequency of getting clear reason for non-delivery of proper electricity service, applying complain for concerned body and its outcome

\begin{tabular}{|c|c|c|c|c|c|c|}
\hline Item & Indicator) & Category & Frequency & $(\%)$ & $\left(\chi^{2}\right)$ & $\begin{array}{l}\text { P- } \\
\text { Value }\end{array}$ \\
\hline \multirow[t]{3}{*}{1} & \multirow{3}{*}{$\begin{array}{l}\text { In case you do not receive proper } \\
\text { electricity service delivery, do you get } \\
\text { clear reason or answer for the reason? } \\
\text { delivered? }(\mathrm{n}=264\end{array}$} & Yes & 30 & $11.4 \%$ & \multirow[b]{3}{*}{13.410} & \multirow[b]{3}{*}{0.001} \\
\hline & & No & 234 & $88.6 \%$ & & \\
\hline & & Total & 264 & $100 \%$ & & \\
\hline \multirow[t]{3}{*}{2} & \multirow{3}{*}{$\begin{array}{l}\text { In the case of non-delivery of electricity } \\
\text { services, did you manage to lodge a } \\
\text { complaint with the designated officer or } \\
\text { other concerned officials?(n=264) }\end{array}$} & Yes & 217 & $82.2 \%$ & \multirow[b]{3}{*}{13.410} & \multirow[b]{3}{*}{0.001} \\
\hline & & No & 47 & $17.8 \%$ & & \\
\hline & & Total & 264 & $100 \%$ & & \\
\hline \multirow[t]{4}{*}{3} & \multirow[t]{4}{*}{ If yes, what was the outcome? $(n=217)$} & $\begin{array}{l}\text { I got immediate } \\
\text { service }\end{array}$ & 3 & $1.4 \%$ & \multirow[b]{4}{*}{7.920} & \multirow[b]{4}{*}{0.048} \\
\hline & & I got waiting a lot & 99 & $45.6 \%$ & & \\
\hline & & they don't react at all & 115 & $53.0 \%$ & & \\
\hline & & Total & 217 & $100 \%$ & & \\
\hline
\end{tabular}

As item number 1 of the table 3 shows, around $30(11.4 \%)$ of respondents responded to get clear reason for non- delivery of service, whereas $234(88.6 \%)$ of respondents claimed that they do not clear reason for nondelivery of service. This goes with statistically significant $\left(\chi^{2}=13.410, \mathrm{P}=0.001\right)$ association of adequate service delivery with getting clear reason/answer for non-delivery of electricity service.

Item number 2 of the same table specifies about public complaints for non-delivery of proper electricity service. It is shown that about $217(82.2 \%)$ of the respondents said yes or apply complaints on non-delivery of service for concerned authorities. On the other hand, around $47(17.8 \%)$ of respondents did say not make a complaint to the concerned authorities.

Still, in item number 3 the table indicates regarding the response of concerned bodies. About 3 (1.4\%) of the respondents have claimed that service users complaints have responded that problem is solved on immediately base. Around 99 (45.6\%) of respondents have replied that the responses of concerned bodies of electricity sector are too late. Whereas, $115(53.0 \%)$ of respondents have said that the concerned bodies of electricity sector do not react at all for complaints of service users. Statistical analysis indicates for existence of a significant association $\left(\chi^{2}=7.920, \mathrm{p}=0.048\right)$ between adequate service delivery and responsiveness.

Table 4: The sector's response to Electricity-related faults

\begin{tabular}{l|llll}
\hline Speed of response $(\mathrm{n}=264)$ & Frequency & Percent $(\%)$ & $\left(\chi^{2}\right)$ & P-Value \\
\hline Very Quick & 2 & $0.8 \%$ & & \\
Quick & 5 & $1.9 \%$ & & \\
Slow & 92 & $34.8 \%$ & & \\
Very Slow & 165 & $62.5 \%$ & 13.410 & 0.009 \\
Total & 264 & $100 \%$ & &
\end{tabular}

As the data in the table 4 indicates, the rate of respondents to the sector's effort to customer response as very slow is rated with majority percentage, which is $(62.5 \%)$. On the other hand, around, $(34.8 \%)$ of the respondents reported to be slow, about $(1.9 \%)$ of respondents reported as quick, while only $(0.8 \%)$ of respondents have replied to be very quick. In addition to this, focus group discussions and interviews with respondents reveal the problem to exist. As they said "the main problems that exist in electricity sector is lack of physical resources like cables and other related resources". These could be said to be main reason for delay of response to service users. Adequate service delivery in-relation to sector very slow response was revealed to have statistically significant association $\left(\chi^{2}=13.410, \mathrm{p}=0.009\right)$.

4.2.1.2. The level of customer satisfaction on electricity supply

Table 5: Overall Satisfactions of Customers on Electricity Service Delivery Process

\begin{tabular}{|c|c|c|c|c|c|}
\hline Indicator & Category & Frequency & $(\%)$ & $\left(\chi^{2}\right)$ & P-Value \\
\hline \multirow{3}{*}{$\begin{array}{l}\text { In your opinion, how satisfied are } \\
\text { you with the electricity service } \\
\text { provided by the sector? }(\mathrm{n}=270)\end{array}$} & Satisfied & 6 & $2.2 \%$ & \multirow[b]{4}{*}{3.840} & \multirow[b]{4}{*}{0.000} \\
\hline & Somehow satisfied & 70 & $259 \%$ & & \\
\hline & Dissatisfied & 194 & $71.9 \%$ & & \\
\hline & Total & 270 & $100 \%$ & & \\
\hline
\end{tabular}

It is shown above in Table 5 that 70 (25.9\%) customer respondents of 'town have said to be somehow satisfied whereas $194(71.9 \%)$ of have said dissatisfied in electricity service delivery. On the other hand, the 
remaining $6(2.2 \%)$ have replied to be satisfied. The perceived responsiveness to complaints was highly related with satisfaction levels. In this study, dissatisfaction level of respondents is high in service delivery process. Statistical analysis of the data indicated that the presence of significant association $\left(\chi^{2}=\mathbf{3 . 8 4 0}, \mathrm{P}=\mathbf{0 . 0 0 0}\right)$ between adequate service delivery and customary dissatisfaction level on service delivery process.

Similarly, data gained from Focus Group Discussions and interview respondents was also indicative of this reality, "The main problems that exist in sector are as a follows: there is no lack of physical resources like cables and other related resources. In other illustration form, the above table is also shown as follows (figure 2):

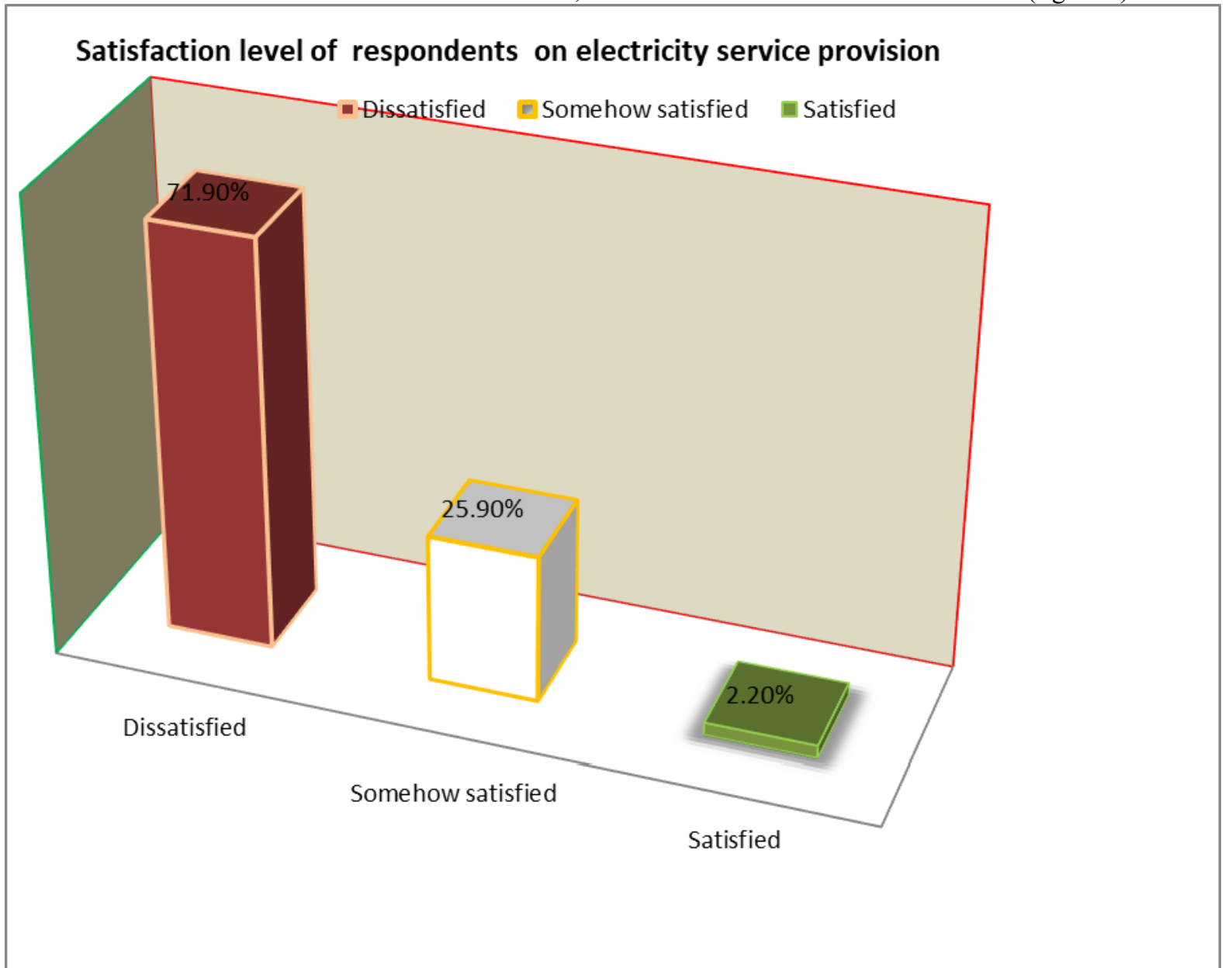

Figure 2: Overall Satisfactions of Customers on electricity Service Delivery Process

Source: the writer's computation based on his data in field survey in 2018.

\subsection{Lack of Transparency}

Table6: Respondents' Reflection on Transparency of sector's Officials/employees, 2018

\begin{tabular}{|c|c|c|c|c|c|}
\hline Indicator & Category & Frequency & $\begin{array}{l}\text { Percentage } \\
(\%)\end{array}$ & $\left(\chi^{2}\right)$ & P-Value \\
\hline \multirow{4}{*}{$\begin{array}{l}\text { Are your sector } \\
\text { employees } \\
\text { transparent? }(n=384)\end{array}$} & not at all & 282 & $73.4 \%$ & \multirow[t]{4}{*}{19.072} & \multirow[t]{4}{*}{0.000} \\
\hline & yes, all & 9 & $2.3 \%$ & & \\
\hline & the majority are not & 93 & $24.2 \%$ & & \\
\hline & Total & 384 & $100 \%$ & & \\
\hline
\end{tabular}

It can be observed from the data that the sector administration suffers from high degree of lack of transparent leadership. This is based on the fact that of the total respondents, the $282(73.4 \%)$ have replied the employee and officials not to be at all transparent, while $93(24.2 \%)$ of them have said that a majority of the employees/officials are not transparent. Thus, it is not surprising that only $9((2.3 \%)$ of the respondents have the belief that they are transparent. Yet, there is considerable agreement between the opinions of respondents above and participants in interviews and in focused group discussion. They admit on majority for the prevalence of lack of transparency in the implementation of the service deliveries of electricity. The statistical analysis of the data showed for the presence of significant association $\left(\chi^{2}=19.072, \mathrm{P}=0.000\right)$ between adequate electricity service delivery and lack of transparency. 
Table 6.1: Survey of respondent opinion on existence of open public discussion with people on issues of electricity supply by sector

\begin{tabular}{|l|l|l|l|}
\hline \multirow{3}{*}{ Public institution } & \multicolumn{3}{|l|}{$\begin{array}{l}\text { Does your electricity sector carry out open discussion with people on issues of service } \\
\text { delivery? }\end{array}$} \\
\cline { 2 - 4 } & Category & Frequency & Percentage (\%) \\
\hline \multirow{3}{*}{ Electricity sector } & Never & 340 & $88.5 \%$ \\
\cline { 2 - 4 } & Sometimes & 44 & $11.5 \%$ \\
\cline { 2 - 4 } & Always & - & - \\
\cline { 2 - 4 } & Total & 384 & $100 \%$ \\
\hline
\end{tabular}

A survey of the data in the table (table 6.1) reveals the reality of sufferance of the town people from the lack of participation in open discussion. The largest number of the respondents or that constitute $340(88.5 \%)$ admit this view, while 44 (11.5) of them believe that on the basis of sometimes consideration. In the information based on interviews and focused groups discussion participants generally believe that as a problem this is a real phenomenon.

Some of the sector officials and employees were approached to provide their reaction on this issue. They did not deny it but at the same told that they had discussion forums arranged with the people on some topics such as action of plan of the sector. Understandably, this is also not completely denied by the respondents. But, where the contradiction most lies is that the respondents argue the discussions not to be arranged for solving burning issue of the town community. They believe to be organized for mere formality to say that 'we have had done it'. Lack of transparency and open discussion further leads to another problems, for example, corruption which is a subject of the following section. It is also interesting to note that focus group discussion participants for this study also have witnessed the prevalence of unethical or there is highly illegal behaviour of officials in the study towns. The leadership of the towns are blamed to be self-centred who always tend to run after corruption. At the heart of the respondents' worry is why it continues while the government bodies are claiming to be devoted to its fight. As it has come rampant, more and more dedication is required to abolish this bad practice, so deeds should show the reality than words.

\section{Conclusion Summary of the Study; Findings, Conclusion and Recommendation 5.1 Summary of Electricity Supply-related Findings}

As indicated in the discussion chapters, this is despite the fact that of the total respondents about 82.2 percent of them duly apply whenever problems of electricity breaks occur. Most households have reported electricity service facility is somewhat extended to significant part of the two town people. The problem however is with the supply that breaks off basis due to power interruption. This, as about 58 per cent of respondents reported, occurs at least once in a week.

\subsection{General Conclusion and Recommendation}

\subsection{Conclusion}

There is poor governance in providing issues focused by this study. On average, in their electricity service delivery fell short of plan and public consultation. The main finding of this study has shown that the electricity supply process of the two towns regarded by majority respondents ineffective, unable to meet standard of customers' expectation.

\subsubsection{Recommendation}

Based on the findings of this study recommends the following challenges to be concerns of improvement.

- The sector should provide sustainable electricity supply. Table-2 of item 2 indicates that, 96.3\% of respondents indicated that they have electricity supply problem. This problem is mostly occurred in weekly. Table- 2 of item 3 also indicates that, $58.0 \%$ of the respondents reported that electricity supply problem was occurred weekly.

- The sector must enhance transparency that help to give clear reason/answer for households who are not receive proper electricity service.

- They must emphasize on open government management in order to resolve local affairs. They should be responsive, transparent and open to public judgment by establishing offices that could receive and settle people complaints. They should have commitment to bring irresponsible workers and officials to due process of law for every criminal act against the citizen's interest.

- In terms of the low electricity, service expansion involves also the Ethiopian Electricity Power Authority whose accountability goes to the federal government. However, the public needs should be clearer to the lower units that must consult with the local representatives of the power agents for improvement.

\section{Reference}

- Avila, N., Carvallo, J. P., Shaw, B. and Kammen, D. M, The energy challenge in sub-Saharan Africa: A 
guide for advocates and policy makers: Part 1: Generating energy for sustainable and equitable development. Oxfam Research Backgrounder series (2017): https://www.oxfamamerica.org/static/media/files/oxfamRAEL-energySSA-pt1.pdf

- Goharipour .H., M. Karimi ,\& N. Barakpour ,2011, 'Evaluation of urban management performance based on citizen satisfaction with municipal services in city of Tehran', Int. Conference on Social Science and Humanity IPEDR .vol.5 ( (C) IACSIT Press), Singapore

- Hanna, R., S .Bishop, S. Nadel, G. Scheffler, K. Durlacher ,2011 'The effectiveness of anti-corruption policy: what has worked, what hasn't, and what we don't know'-a systematic review. Technical report. London: EPPI-Centre, Social Science Research Unit, Institute of Education, University of London.

- Japanese report, 2008, 'Study on the Energy Sector in Ethiopia'

- Jefferson.T. ,Bachmann.J., MacCleery.R.,2007, 'Managing Municipal Services Delivery’ , United States Agency for International Development, Washington DC, USA.

- Oertel .S. 2004, 'Measuring and Monitoring Progress towards Good Governance in Africa: Governance Profile of Ethiopia', Economic Commission for Africa, Addis Ababa, Ethiopia

- Shimelis Alebachew , 2003 , 'Municipal Development Partnership Eastern and Southern Africa, Urban th

Service Delivery: The case of Addis Ababa, Ethiopia', The 5 Urban and City Management Course for Africa Organized by: MDP ESA, WBI and GDLN Centers in Africa (Ethiopia, Kenya, Ghana, Tanzania and Uganda), Module - 4

- UNDP, 2010, 'The impact of good governance on development and poverty in Africa: Botswana - A relatively successful African initiative' in African Journal of Political Science and International Relation.Vol.4(7) pp249-262.

- Zeritu Fikre, 2010, 'Service Delivery and Customer Satisfaction: The Case of Ethiopian Electric Power Corporation Eastern Addis Ababa Region Customer Service Centres MA thesis.' 